\title{
Gambaran Sebab Kematian pada Kasus Ekshumasi di Sulawesi Utara dan Gorontalo Tahun 2016-2018
}

\author{
${ }^{1}$ Adi W. S. Lumuhu \\ ${ }^{2}$ Erwin Kristanto \\ ${ }^{2}$ Nola T. S. Mallo
}
${ }^{\mathbf{1}}$ Program Studi Pendidikan Dokter Fakultas Kedokteran Universitas Sam Ratulangi Manado
${ }^{2}$ Bagian Ilmu Kedokteran Forensik dan Medikolegal Fakultas Kedokteran
Universitas Sam Ratulangi/RSUP Prof. Dr. R. D. Kandou Manado
Email: adilumuhu@gmail.com

\begin{abstract}
Exhumation is removing buried corpse to reidentify the corpse due to suspicion of the cause of death by the authorities. This study was aimed to obtain the causes of deaths of exhumated cases in North Sulawesi and Gorontalo during years 2016 to 2018. This study was conducted at the Forensic Medicine and Medicolegal Department of Prof. Dr. R. D. Kandou Hospital, Manado. This was a descriptive and retrospective study using data of Visum et Repertum. There were 10 exhumated cases during those years. Most cases were male ( 5 cases $\sim 50 \%)$. The dominating sex was male $(6$ cases $\sim 60 \%)$. The highest number of age was 14 years ( 3 cases $\sim 30 \%$ ). Of 10 exhumated cases, the causes of deaths could be determined in 8 cases. The most fequent causes of deaths was blunt trauma on the head that caused brain tissue injuries ( 4 cases $\sim 40 \%$ ). In two baby corpses, the causes of deaths could not be determined since both lungs were decomposed and the other baby was a stillbirth. In conclusion, most death causes of exhumated cases in North Sulawesi and Gorontalo registered during years 2016 to 2018 at Prof. Dr. R. D. Kandou Hospital Manado could be determinedand and the main cause of death was blunt trauma on the head that caused brain tissue injury
\end{abstract}

Keywords: exhumation, cause of death

\begin{abstract}
Abstrak: Ekshumasi adalah penggalian jenazah untuk mengidentifikasi kembali jenazah karena timbulnya kecurigaan terhadap kematian seseorang oleh pihak berwenang. Penelitian ini bertujuan untuk mengetahui gambaran sebab kematian pada kasus ekshumasi di Sulawesi Utara dan Gorontalo tahun 2016-2018. Penelitian dilakukan di Bagian Ilmu Kedokteran Forensik dan Medikolegal RSUP Prof. Dr. R. D. Kandou Manado. Jenis penelitian ialah deskriptif retrospektif menggunakan hasil Visum et Repertum. Hasil penelitian mendapatkan 10 kasus ekshumasi selama tahun 2016-2018. Kasus terbanyak yaitu pada tahun 2016 yaitu 5 kasus (50\%). Jenis kelamin jenazah didominasi oleh laki-laki sebanyak 6 kasus (60\%). Usia terbanyak ialah 14 tahun berjumlah 3 kasus (30\%). Dari 10 kasus ekshumasi, 8 kasus dapat ditentukan sebab kematian dengan sebab kematian terbanyak ialah kekerasan tumpul pada bagian kepala yang menyebabkan kerusakan jaringan otak pada 4 kasus $(40 \%)$. Pada dua kasus bayi, sebab kematian tidak dapat ditentukan karena kedua paru sudah sangat membusuk sedangkan bayi lainnya lahir tidak bernapas. Simpulan penelitian ini ialah secara keseluruhan sebab kematian pada kasus ekshumasi di Sulawesi Utara dan Gorontalo yang masuk di RSUP Prof. Dr. R. D. Kandou tahun 2016-2018 dapat diungkapkan dengan kekerasan tumpul pada bagian kepala yang menyebabkan kerusak-an jaringan otak sebagai sebab kematian utama.
\end{abstract}

Kata kunci: ekshumasi, sebab kematian 
Ekshumasi adalah penggalian jenazah yang secara hukum legal dilakukan oleh pihak bewewenang yang bertujuan untuk mengidentifikasi kembali jenazah karena timbunya kecurigaan terhadap kematian seseorang yang baru timbul setelah dilaksanakan penguburan atau dengan sengaja menghilangkan kejahatan dengan dilakukan penguburan. Ekshumasi dilakukan oleh dokter ahli kedokteran forensik atas perintah penyidik (Kitab Undang- Undang Hukum Acara Pidana pasal 134, pasal 135, dan pasal 136) yang bertujuan untuk membuat terang dan jelas suatu perkara terlebih khusus perkara pidana melalui pemeriksaan tubuh korban untuk menentukan sebab kematian. ${ }^{1-3}$

Ekshumasi biasanya dilakukan ketika kasus kematian seseorang dianggap tidak wajar. Kematian tidak wajar adalah kematian yang bukan akibat suatu penyakit seperti kecelakaan (accident), pembunuhan (homocide), dan bunuh diri (suicide). ${ }^{4}$ Negaranegara yang memiliki tingkat autopsi yang rendah, salah satunya Belgia, ekshumasi biasa dilakukan untuk masalah dalam asuransi kesehatan, penelitian ilmiah, studi arkeologi, taphonomy, dan identifikasi genetik. $^{5,6}$ Di negara yang memiliki hukum Yahudi, pelaksanaan ekshumasi dilarang karena orang yang telah meninggal dan dikubur serta bagaimanapun kondisinya harus dijaga dan dihormati.

Ekshumasi sangat berperan penting dalam mengungkapkan sebab kematian. Sebab kematian lebih mengarah kepada alat atau sarana yang dipakai untuk mematikan korban sehingga sebab kematian jangan disalahartikan dengan mekanisme kematian karena mekanisme kematian lebih menjelaskan bagaimana korban mati setelah penyebab kematian terjadi. ${ }^{8}$ Beberapa contoh kasus ekshumasi yang telah dilakukan di Indonesia selama tahun 2016-2019 untuk mencari tahu penyebab kematian korban yaitu kematian Riyanti yang diduga kasus aborsi ilegal di Kota Magelang Jawa Tengah; kematian anggota Paskhas TNI AU Praka Yudha Prihanto di Kota Malang Jawa Timur; kematian Balita Mantandoi di Kabupaten Bolaang Mongondow Selatan
Sulawesi Utara; dan kematian Imam Satria di Kabupaten Muba Sumatera Selatan. ${ }^{9-12}$

Kasus ekshumasi di Sulawesi Utara dan Gorontalo masih sedikit dijumpai dan informasi tentang kasus ekshumasi di daerah ini masih sangat minim sehingga dibutuhkan sumber, data, dan penelitian lainnya tentang kasus ekshumasi. Penelitian ini bertujuan untuk mengetahui gambaran sebab kematian pada kasus ekshumasi di Sulawesi Utara dan Gorontalo pada tahun 2016-2018.

\section{METODE PENELITIAN}

Penelitian ini dilakukan pada periode bulan September-November 2019. Jenis penelitian ialah deskriptif retrospektif dengan menggunakan data Visum et Repertum yang diambil di Bagian Ilmu Kedokteran Forensik dan Medikolegal RSUP Prof. Dr. R. D. Kandou Manado. Subjek penelitian ialah seluruh data kasus ekshumasi di Sulawesi Utara dan Gorontalo dalam Visum et Repertum di Bagian Ilmu Kedokteran Forensik dan Medikolegal FK Universitas Sam Ratulangi dan RSUP Prof. Dr. R. D. Kandou Manado periode 20162018. Variabel penelitian ialah jumlah kasus ekshumasi, usia, jenis kelamin, dan sebab kematian.

\section{HASIL PENELITIAN}

Tabel 1 memperlihatkan bahwa berdasarkan data rekam medik di Bagian Ilmu Kedokteran Forensik dan Medikolegal RSUP Prof. Dr. R. D. Kandou Manado didapatkan jumlah kasus eskhumasi di Sulawesi Utara dan Gorontalo tahun 20162018 ialah 10 kasus.

Tabel 1. Jumlah kasus ekshumasi

\begin{tabular}{ccc}
\hline Tahun & $\begin{array}{c}\text { Jumlah } \\
\text { kasus }\end{array}$ & $\begin{array}{c}\text { Persentase } \\
(\%)\end{array}$ \\
\hline 2016 & 5 & 50 \\
2017 & 4 & 40 \\
2018 & 1 & 10 \\
Total & 10 & 100 \\
\hline
\end{tabular}

Tabel 2 memperlihatkan bahwa berdasarkan data jenis kelamin, didapatkan 10 kasus ekshumasi yang terdiri dari 6 jenazah 
laki-laki dan 4 jenazah perempuan.

Tabel 2. Distribusi kasus ekshumasi berdasarkan jenis kelamin

\begin{tabular}{ccc}
\hline $\begin{array}{c}\text { Jenis } \\
\text { kelamin }\end{array}$ & $\begin{array}{c}\text { Jumlah } \\
\text { kasus }\end{array}$ & $\begin{array}{c}\text { Persentase } \\
(\boldsymbol{\%})\end{array}$ \\
\hline Laki-laki & 6 & 60 \\
Perempuan & 4 & 40 \\
Total & 10 & 100 \\
\hline
\end{tabular}

Tabel 3 memperlihatkan distribusi usia kasus ekshumasi dengan usia 14 tahun ialah usia terbanyak berjumlah 3 kasus.

Tabel 4 memperlihatkan data sebab kematian pada kasus ekshumasi; yang terbanyak ialah kekerasan tumpul pada bagian kepala yang menyebabkan kerusakan jaringan otak sebanyak 4 kasus (40\%).

Tabel 3. Distribusi kasus ekshumasi berdasarkan usia

\begin{tabular}{ccc}
\hline Usia & $\begin{array}{c}\text { Jumlah } \\
\text { kasus }\end{array}$ & $\begin{array}{c}\text { Persentase } \\
(\%)\end{array}$ \\
\hline 14 tahun & 3 & 30 \\
16 tahun & 1 & 10 \\
17 tahun & 1 & 10 \\
49 tahun & 1 & 10 \\
Usia kehamilan & 2 & 20 \\
belum 28-30 minggu & & \\
Tidak diketahui & 2 & 20 \\
Total & 10 & 100 \\
\hline
\end{tabular}

Tabel 4. Kasus ekshumasi berdasarkan sebab kematian

\begin{tabular}{|c|c|c|}
\hline No & Identitas & Sebab kematian \\
\hline 1 & $\begin{array}{l}\text { Laki-laki, } \\
14 \text { tahun }\end{array}$ & $\begin{array}{l}\text { Kekerasan tumpul pada dahi menyebabkan kerusakan jaringan otak } \\
\text { Korban tenggelam atau masuknya cairan yang cukup banyak ke dalam } \\
\text { saluran nafas paru, sehingga mati lemas }\end{array}$ \\
\hline 2 & $\begin{array}{l}\text { Perempuan, } \\
17 \text { tahun }\end{array}$ & $\begin{array}{l}\text { Tergantung, menyebabkan terhalangnya saluran nafas bagian atas } \\
\text { sehingga terjadi mati lemas }\end{array}$ \\
\hline 3 & $\begin{array}{l}\text { Perempuan, } \\
14 \text { tahun }\end{array}$ & $\begin{array}{l}\text { Kekerasan tumpul pada daerah kepala bagian belakang yang } \\
\text { menyebabkan kerusakan dan perdarahan otak }\end{array}$ \\
\hline 4 & Bayi laki-laki & $\begin{array}{l}\text { Lahir bernapas atau tidak bernapas tidak dapat ditentukan sebab kematian } \\
\text { kedua paru sudah sangat membusuk dan tidak dapat diperiksa lagi }\end{array}$ \\
\hline 5 & Bayi perempuan & Lahir tidak bernapas karena tidak pernah hidup \\
\hline 6 & $\begin{array}{l}\text { Perempuan, } \\
14 \text { tahun }\end{array}$ & $\begin{array}{l}\text { Kekerasan tumpul pada daerah kepala bagian belakang yang } \\
\text { menyebabkan kerusakan dan perdarahan otak }\end{array}$ \\
\hline 7 & Laki-laki muda & $\begin{array}{l}\text { Tergantung menyebabkan terhalangnya saluran nafas bagian atas } \\
\text { sehingga terjadi mati lemas }\end{array}$ \\
\hline 8 & Laki-laki muda & Luka-luka bacok pada kepala yang menyebabkan rusaknya jaringan otak \\
\hline 9 & $\begin{array}{l}\text { Laki-laki, } \\
49 \text { tahun }\end{array}$ & $\begin{array}{l}\text { Perdarahan kelenjar ludah perut (pankreatitis akut atau peradangan } \\
\text { mendadak kelenjar ludah perut) }\end{array}$ \\
\hline \multirow[t]{2}{*}{10} & $\begin{array}{l}\text { Laki-laki, } \\
16 \text { tahun }\end{array}$ & $\begin{array}{l}\text { Kekerasan tumpul pada daerah pelipis kiri yang menyebabkan kerusakan } \\
\text { jaringan otak }\end{array}$ \\
\hline & & $\begin{array}{l}\text { Kekerasan pada dada kanan menyebabkan terjepitnya paru kanan dengan } \\
\text { dinding dada sehingga mngakibatkan terjadi luka lecet tekan dan robek, } \\
\text { resapan darah luas pada jaringan paru kanan }\end{array}$ \\
\hline
\end{tabular}

\section{BAHASAN}

Ekshumasi adalah penggalian jenazah yang jarang dilakukan dan hanya pada kasus-kasus tertentu saja atas perintah penyidik untuk membuat terang dan jelas suatu perkara terlebih khusus perkara pidana melalui pemeriksaan tubuh korban. Prosedur dalam melaksanakan ekshumasi pada prinsipnya harus dilakukan sesegera mungkin agar dalam pemeriksaan masih banyak bukti yang dapat ditemukan dan dari segi persiapan sampai pelaksanaan ekshumasi harus dilakukan dengan teliti sesuai prosedur yang telah ditentukan. Peran dokter sebagai saksi ahli sangat penting dalam melakukan pemeriksaan 
tubuh jenazah yang dilakukan ekshumasi dan memberi simpulan dari hasil pemeriksaan untuk ditindaklanjuti oleh pihak yang berwenang yaitu penyidik (kepolisian).

Hasil penelitian ini mendapatkan sebanyak 10 kasus ekshumasi di Sulawesi Utara dan Gorontalo pada data Visum et Repertum Bagian Ilmu Kedokteran Forensik dan Medikolegal FK Universitas Sam Ratulangi/RSUP Prof. Dr. R. D. Kandou Manado selama tahun 2016-2018. Pada tahun 2016 terdapat 5 kasus ekshumasi (50\%), kemudian pada tahun 2017 mengalami penurunan jumlah kasus sebanyak 4 kasus (40\%), dan terakhir pada tahun 2018 hanya didapatkan 1 kasus ekshumasi (10\%) yang menunjukkan terdapat tren penurunan jumlah total pemeriksaan kasus ekshumasi. Kristanto $^{13}$ melaporkan bahwa terjadi kenaikan angka pemeriksaan bedah jenazah pada tahun 2015-2019 di Sulawesi Utara. Perbedaan hasil ini disebabkan karena Kristanto menggunakan dua rumah sakit di Kota Manado yaitu RSUP Prof. Dr. R. D. Kandou dan RS Bhayangkara tingkat III Manado sedangkan penelitian ini hanya menggunakan satu rumah sakit saja yaitu RSUP Prof. Dr. R. D. Kandou dengan jumlah pemeriksaan kasus ekshumasi yang lebih rendah.

Dalam penelitian ini didapatkan Polsek permintaan kasus ekshumasi di daerah Sulawesi Utara yaitu 8 kasus dan Polsek permintaan kasus ekshumasi di daerah Gorontalo yaitu 2 kasus. Dari 10 Surat Visum et Repertum semua kasus dilakukan pemeriksaan autopsi sehingga dapat diasumsikan pihak kepolisian memiliki penanganan yang baik dalam menangani kasus ekshumasi tersebut serta adanya kesadaran masyarakat dalam melaporkan kasus kepada penyidik yang perlu dilakukan autopsi setelah dikubur.

Kasus ekshumasi berdasarkan jenis kelamin yaitu 6 jenazah laki-laki $(60 \%)$ dan 4 jenazah perempuan (40\%) sehingga dapat disimpulkan bahwa jumlah kasus ekshumasi pada tahun 2016-2018 lebih banyak dilakukan pada jenazah laki-laki dibandingkan jenazah perempuan. Hasil penelitian ini selaras dengan penelitian oleh
Kristanto $^{13}$ yang melaporkan bahwa terdapat 22 kasus pemeriksaan kedokteran forensik pada jenazah hasil ekshumasi tahun 2015-2019 di Sulawesi Utara yang terdiri atas 17 jenazah laki-laki $(77 \%)$ dan 5 jenazah perempuan (23\%). Demikian pula halnya dengan penelitian sebelumnya oleh Lolong et $\mathrm{al}^{14}$ tahun 2015-2016 yang mendapatkan dari 9 kasus ekshumasi, 8 di antaranya berjenis kelamin laki-laki.

Hasil penelitian ini mendapatkan bahwa berdasarkan usia kasus ekshumasi terbanyak pada usia 14 tahun (3 kasus). Kasus ekshumasi ini didominasi dengan batasan usia anak berdasarkan UndangUndang Republik Indonesia Nomor 23 Tahun 2002 tentang Perlindungan Anak, pasal 1 Ayat 1 , yaitu Anak adalah seseorang yang belum berusia 18 (delapan belas) tahun, termasuk anak yang masih dalam kandungan. ${ }^{15}$

Pada penelitian ini didapatkan kasus ekshumasi berdasarkan sebab kematian terbanyak ialah kekerasan tumpul pada bagian kepala yang menyebabkan kerusakan jaringan otak sebanyak 4 kasus (40\%), diikuti sebab kematian karena tergantung yang menyebabkan terhalangnya saluran napas bagian atas sehingga mati lemas sebanyak 2 kasus (20\%), dan sisanya yaitu kekerasan tajam dan tenggelam. Kristanto ${ }^{13}$ melaporkan bahwa sebab kematian yang diperoleh pada mayoritas kasus ekshumasi yang diperiksa $(95,45 \%)$ ialah kekerasan tumpul pada berbagai daerah tubuh.

Dari 10 kasus ekshumasi yang dilakukan pada tahun 2016-2018 didapatkan 8 kasus dapat ditentukan sebab kematiannya sedangkan pada 2 kasus tidak ditemukan sebab kematiannya dikarenakan sebelumnya jenazah tersebut tidak pernah hidup (usia kehamilan belum cukup bulan yaitu belum mencapai 28-30 minggu kehamilan). Hal ini sejalan dengan yang dikemukakan oleh Kristanto ${ }^{13}$ yang mendapatkan bahwa sebab kematian dapat ditentukan pada 95,45\% kasus ekshumasi.

\section{SIMPULAN}

Berdasarkan hasil penelitian ini dapat disimpulkan bahwa secara keseluruhan 
sebab kematian pada kasus ekshumasi di Sulawesi Utara dan Gorontalo yang masuk di RSUP prof. Dr. R. D. Kandou Manado tahun 2016-2018 dapat diungkapkan dengan sebab kematian utama ialah kekerasan tumpul pada bagian kepala yang mengakibatkan kerusakan jaringan otak.

Bagi penelitian selanjutnya diharapkan dapat menambah variabel penelitian agar hasil penelitian dapat lebih luas lagi. Ekshumasi dijadikan topik yang secara khusus dibahas dalam Ilmu Kedokteran Forensik dan Medikolegal agar calon dokter mendapatkan gambaran atas perannya dalam ekshumasi

\section{DAFTAR PUSTAKA}

1. Budiyanto A, Widiatmaka W, Sudiono S, Mun'im TWA, Hertian S, Sampurna, et al. Ilmu Kedokteran Forensik. Jakarta: Bagian Kedokteran Forensik Fakultas Kedokteran Universitas Indonesia, 1997; p. 203-206

2. Wyatt J, Squires T, Norfolk J, James JP. Oxford Handbook of Forensic Medicine. New York: Oxford University Press, 2011; p. 89

3. Sudjari S. Buku Ajar llmu Kedokteran Forensik dan Medikolegal (7th ed). Surabaya: Departemen llmu Kedokteran Forensik dan Medikolegal Fakultas Kedokteran Universitas Airlangga, 2010; p. 196-200

4. Dinas Kedokteran dan Kesehatan Polri. Buku Pegangan Ilmu Kedokteran Forensik Edisi keempat. Jakarta: Lembaga Kedokteran Kepolisian Unit Kedokteran Forensik,1996.

5. James JP, Jones R, Karch SB, Manlove J. Simpson's Forensic Medicine (13th ed). London: Hodder \& Stoughton Ltd, 2011; p. 33.

6. Guimarães MA Francisco RA, Evison M, Iwamura ESM, Machado CEP, Silva RHA, et al. Procedural and political aspects of forensic exhumation in Brazil. Human Remains and Violence. 2017; 3(1):37-51.
7. Lamm M. The Jewish way in death and mourning 'The Grave'. [Cited 2019 Aug 25] Available from: http://www.chabad. org/library/article_cdo/aid/281579/jewish /The-Grave.htm

8. Idries AM, Tjiptomartono AL. Penerapan Ilmu kedokteran Forensik dalam proses penyelidikan (edisi revisi). Jakarta: Sagung Seto, 2008; p.48-50, 204-6.

9. Kompas.com. Diduga korban aborsi ilegal, makam Riyati dibongkar polisi. 19 Juli 2016 [cited 2019 Aug 13]. Available from: https://regional.kompas.com/read/ 2016/07/19/14123111/.diduga.korban.ab orsi.ilegal.makam.riyati.dibongkar.polisi

10. Kompas.com. Dibongkar, makam anggota Paskhas TNI AU yang tewas di markasnya. 24 Mei 2017 [cited 2019 Aug 13]. Available from: https://regional. kompas.com/read/2017/05/24/08321531/ dibongkar.makam.anggota.paskhas.tni.au .yang.tewas.di.markasnya

11. Tribunnews.com. Makam balita Matandoi digali untuk diautopsi. 05 Oktober 2017 [ cited 2019 Aug 13]. Available from: https://manado.tribunnews.com/2017/10/ 05/makam-balita-matandoi-digali-untukdiautopsi

12. Palpos.id. Diduga ada kejanggalan, makam imam dibongkar. 2 Juli 2019 [cited 2019 Aug 13]. Available from: https://palpos. id/ 2019/07/02/diduga-ada-kejanggalanmakam-imam-dibongkar/

13. Kristanto E. Pemeriksaan kedokteran forensik setelah ekshumasi di Sulawesi Utara: Kontribusi dan tantangan. Jurnal Biomedik. 2019;11(3):192-8.

14. Lolong G, Mallo NTS, Mallo JF. Efektivitas ekshumasi dalam pengungkapan kasus di Bagian Ilmu Kedokteran Forensik dan Medicolegal FK Unsrat - RSUP Prof. Dr. R. D. Kandou tahun 2015-2016. e-CliniC. 2017;5(1):83-6.

15. Undang-Undang Republik Indonesia Nomor 23 Tahun 2002 tentang Perlindungan Anak [cited 12 Nov 2019] Available from: https://pih.kemlu.go.id/files/ UUNo23tahun2003PERLINDUNGANA NAK.pdf 